\title{
Supporting Innovation in Organic Agriculture: A European Perspective Using Experience from the SOLID Project
}

\author{
Susanne Padel ${ }^{1}$, Mette Vaarst ${ }^{2} \&$ Konstantinos Zaralis $^{1}$ \\ ${ }^{1}$ The Organic Research Centre, Near Newbury, United Kingdom \\ ${ }^{2}$ International Centre for Research in Organic Food Systems, Tjele, Denmark \\ Correspondence: Susanne Padel, The Organic Research Centre, Elm Farm, Hamstead Marshall, Newbury RG20 \\ 9HR, United Kingdom. Tel: 44-1488-658298 ext. 552. E-mail: susanne.p@organicresearchcentre.com
}

\author{
Received: February 15, 2015 Accepted: April 3, $2015 \quad$ Online Published: June 20, 2015 \\ doi:10.5539/sar.v4n3p32 \\ URL: http://dx.doi.org/10.5539/sar.v4n3p32
}

\begin{abstract}
Organic farming is recognized as one source for innovation helping agriculture to develop sustainably. However, the understanding of innovation in agriculture is characterized by technical optimism, relying mainly on new inputs and technologies originating from research. The paper uses the alternative framework of innovation systems describing innovation as the outcome of stakeholder interaction and examples from the SOLID (Sustainable Organic Low-Input Dairying) project to discuss the role of farmers, researchers and knowledge exchange for innovation. We used a farmer-led participatory approach to identify problems of organic and low-input dairy farming in Europe and develop and evaluate innovative practices. Experience so far shows that improvements of sustainability can be made through better exploitation of knowledge. For example, it is recognized that optimal utilization of good quality forage is vitally important, but farmers showed a lack of confidence in the reliability of forage production both in quantity and quality. We conclude that the systems framework improves the understanding of innovation processes in organic agriculture. Farmer-led research is an effective way to bring together the scientific approach with the farmers' practical and context knowledge in finding solutions to problems experienced by farmers and to develop sustainability.
\end{abstract}

Keywords: innovation systems, innovation process, organic agriculture, farmer-led research, SOLID, TP organics

\section{Introduction}

Innovation and agriculture have always gone 'hand-in-hand' because working with dynamic geographic, climatic, market and political conditions requires constant change (EC-SCAR, 2012). According to Hoffman et al. (2007) farmers have been developing agricultural practices since the beginning of agriculture, about 10,000 years ago. Their innovative power can be seen in many crops species grown and in different animal breeds, in the development of new production systems, farm machinery and equipment and also in social innovations (Hoffmann et al., 2007). Today innovation is seen as the primary instrument for overcoming the sustainability challenges of agriculture at the beginning of $21^{\text {st }}$ century, such as food security, climate change and the conservation of natural resources. The European Innovation Partnership for Agricultural Productivity and Sustainability (EIP-AGRI) was set up in response to these challenges (EIP-AGRI, 2012).

Organic farming is recognized as one source for innovation helping agriculture to overcome such challenges: "Organic farming with its stringent rules on external input use has to be even more innovative to solve production problems, sometimes opening up new avenues" (McIntyre et al., 2009, p. 384). The European Technology Platform TP Organics describes organic farms as "creative living laboratories for smart and green innovations" (Padel et al., 2010). Organic farming can make an important contribution and will continue to innovate in order to adapt to changing conditions in the climate as well as in the developing market.

However, innovation in agriculture is currently frequently understood as referring exclusively to the need for new inputs and technologies that originate from research (Röling, 2009). Garnet and Godfray (2012) referred to this as technological optimism in the debate about sustainable intensification. Much of the agricultural research effort in the last century has been concerned with developing and using external inputs (such as fertilizers and germplasm). Understanding how farmers adopt such science derived innovation was the starting point for the 
model of adoption and diffusion of innovation (Rogers, 1983). This led to the technology transfer model of the green revolution, where research was seen as the main generator of innovation that had to be transferred to and adopted by the farmers. The adoption/diffusion model was applied to organic farming by Padel (2001). She concluded that early organic farmers share many characteristics with other innovators. However, organic farming could not be characterized as a typical innovation, because it requires complex change, brings often no recognized economic advantage, conflicts with some rural values and is knowledge-intensive, whilst access to information is limited (Padel, 2001). This clearly limits the usefulness of the adoption/diffusion model to understand innovation in the organic sector. In Europe, the conceptual framework of innovation systems is gaining in importance for agriculture (EC-SCAR, 2011) and is underlying the new instrument of the Innovation Partnership of the European Union (EIP-AGRI, 2012).

In this paper we explore how innovation occurs within the organic sector in Europe and how this process can be further supported, using framework of innovation systems and experiences from the ongoing project 'Sustainable Organic Low-Input Dairying (SOLID)'. We first describe the approach of encouraging stakeholder-led innovation that was used in the project and present experiences gained so far. Based on selected examples, we discuss how innovation potentially can support sustainable development within the farming sector. This challenges the widespread perception that innovation in agriculture is mainly about new technologies and inputs and illustrates the importance of using active sharing of existing knowledge and of close collaboration between farmers and researchers in supporting innovation in this sector.

\subsection{From Technology Transfer to Supporting the Innovation System}

Innovation is a broad concept defined as the development, introduction and application of a new or significantly improved product (good or service), a new marketing method or a new organizational method in business practice, workplace organization or external relations where an economic or social benefit is assumed for individuals, groups or entire organizations (OECD/Eurostat 2005). The concept of 'innovation' is not restricted to invention or a new idea itself, but includes also the embedding of an idea in the relevant sector (Schumpeter et al., 1980).

However, within agriculture innovation is seen mainly as the search for new inputs and technologies (Röling, 2009) while the potential of social/societal innovation for achieving societal and political goals is not recognized (Bokelmann et al., 2012). This maybe not so surprising, given the long period during which "efficiency came ... to mean the application of the new agricultural technologies, which were beginning to emerge onto the market." (Morgan \& Murdoch, 2000). In arable production, the farmers' 'know-how' was replaced by 'know-what', i.e. what input to use and when (Morgan \& Murdoch, 2000). This 'technical optimism' remains strong in contemporary thinking about sustainable intensification of agriculture in the UK, but the need for new perspectives is beginning to be recognized (Garnett \& Godfray, 2012).

In contrast, the concept of innovation systems describes innovation as an interactive evolutionary process, from invention to successful adoption by the target group with different participants involved at various stages (Smiths et al., 2010). Innovation occurs when networks of organizations come together with the institutions and policies that affect innovative behavior and bring new products and processes into economic and social use (various authors cited by Hall et al., 2005). Innovation becomes an emergent property not only of science or the market, but of interaction between stakeholders that allows opportunities to develop (Röling, 2009). The relevance of this concept for agriculture in Europe is increasingly recognized (e.g. Bokelmann et al., 2012, EC SCAR, 2012). The concept of innovation systems differs from the technology transfer framework also in the types of innovation considered, with the former focuses mainly new technologies, whereas the later differentiates between consumer driven, technology driven and organizationally driven pathways to innovation. The European Innovation Platform for Agricultural Productivity and Sustainability that wants to use partnerships and bottom-up approaches, linking farmers, advisors, researchers, businesses, and other participants in so called Operational Groups is based on this concept (EIP-AGRI, 2012).

Following on from Farmer First (Chambers et al., 1989), many authors argue that it is important to put the farmer back at the center of knowledge production (e.g. MacMillan and Benton, 2014). Farmer involvement is thereby critical in all stages of the process, so that novel technologies and practices can be learned directly and then adapted to particular agro-ecological, social and economic circumstances (Pretty et al., 2011). Others refer to 'co-innovation' that can involve a diverse range of participants other than farmers, such as rural entrepreneurs, regional governments, researchers and knowledge brokers (EC-SCAR, 2011; Knickel et al., 2009).

\subsection{The Role of Knowledge in Innovation in the Organic Agriculture Sector}

Innovation is the application of knowledge to achieve desired social and/or economic outcomes. This knowledge 
may be acquired through learning, research or experience, but the process is not considered as innovation until the knowledge is applied more widely (Hall et al., 2005). Sustainable agriculture makes productive use of human and social capital in the form of knowledge sharing to adapt and innovate to resolve common landscape-scale problems (Pretty et al., 2011). The techniques and practises used in organic farming are knowledge intensive (Lockeretz, 1991) and knowledge sharing between farmers is at the heart of the agrecology movement (Wezel et al., 2009).

Faced with new challenges of productivity, environmental change, and market conditions, organic farmers also have to evolve and innovate. Some innovation in organic farming occurs through the reapplication of existing knowledge. The European Technology Platform TP Organics referred to 'know-how innovation' to distinguish innovation that relies entirely on recombining and applying existing knowledge from other technological or social/societal and organizational innovation (Padel et al., 2010). Examples of such 'know-how innovation' include securing essential supply of vitamins and minerals in animal diets from natural sources, using composts for plant protection or encouraging predators by creating suitable habitats (e.g. flowering field margins). The definition of 'know-how innovation' used by the platform is very similar to the concept of exploitative knowledge strategies as compared to explorative ones ( $\mathrm{Li}$ et al., 2008; March, 1991). In an exploitative strategy firms focus on levering existing knowledge to rapidly create new organizational products and processes, whereas in an explorative one they strive to develop capabilities to create or acquire new knowledge. Knowledge exploitation fits well into innovation systems concepts, whereas the explorative knowledge strategy has similarities to concept of 'technological innovation' (e.g. new germplasm or new machinery). TP organics argued that 'know-how innovation' is crucial to the organic farmer's ability to innovate, i.e. to respond effectively to new challenges, such as saving and protection of natural resources, and for improving the multi-functionality and sustainability of agriculture (Padel et al., 2010).

\section{Approach to Encourage Innovation Through Stakeholder Engagement and Participatory Research in the SOLID Project}

The European Union (EU) funded SOLID project (Sustainable Organic Low-Input Dairying) carries out research to improve the sustainability of low-input/organic dairy systems, aiming to improve the health and welfare, productivity and product quality by better understanding how contrasting genotypes adapt to such conditions, and to improve the supply of nutrients from forages and by-products through the use of novel feeds. The five year project also performs environmental, economic and supply chain assessments and promotes knowledge exchange. We report here from one work package that aims to facilitate innovation by actively involving farming stakeholders (i.e. organic and low-input dairy farmers, farmer groups and farm advisors) and stakeholder partners together with researchers in a participatory approach.

We used a farmer-led approach to identify problems of organic and low-input dairy farmers and develop and evaluate some potentially innovative solutions. In addition to research partners (from institutes and universities), the project also involved enterprise partners (small and medium size milk companies (SMEs) that work with groups of organic and low input dairy cow and goat producers in nine countries. The participatory approach progressed in four steps.

1. Identifying topics where farmer feel knowledge or innovation is needed.

2. Developing appropriate research approaches and experimental procedures to test innovative solutions for topics identified in Step 1.

3. Carry out the proposed research with small number of farms or groups of farmers (between one and five per country).

4. Report on the lessons learned and communicate the result to farmers, consultants and researchers.

The work is still on-going so experience has so far mainly been gained with the first and the second step of this approach which are described in some detail here.

\subsection{Identification of Potential Topics for Participatory Research}

The emphasis in this step was on working with producers to identify topics for the development, implementation and analysis of relevant, producer-led projects. At first, we carried out a rapid sustainability assessment on ten farms in each country, encouraging the farmers to think not only about immediate practical needs but reflect on the overall sustainability of their farms. Farms were chosen among the SME members to illustrate the range within low-input and organic farms in terms of size, intensity/level of input use, breeds, products, marketing channels and geographical area in the respective country/region and to highlight potential sustainability hotspots. The assessment of different strands of sustainability used a tool developed by Organic Research Centre adapted 
to the project (Gerrard et al., 2011; Marchand et al., 2014). After some initial hesitation, both farmers and researchers viewed the process mainly positively, but expressed also questions about specific data requests and the validity of some indicators.

The results of the sustainability assessments were presented at meetings, attended by between 10 and 25 farmers, aimed at identifying research needs and constraints of the industry and to formulate potential solutions which could subsequently be tested. A common protocol for the workshops encouraging farmers to discuss successes and innovative or unusual practices on their farms provided a link between everyday practical issues and sustainability, before moving to ideas how to further develop strength and address the perceived problems. The facilitators' role was to draw out areas of common interest related to the farmers' practical situations as well as remaining relevant to the overall issue of sustainability (see Leach et al., 2013 for details of approach).

\subsection{Developing the Appropriate Research Method}

Further discussion between the farmers, SMEs and researchers lead to the narrowing down of suitable research topics and to the setting-up of specific on-farm research projects. Not all topics and themes initially suggested could be investigated, because only a limited number of studies could be carried out. The following methods were used:

- Farm case studies were based on monitoring certain aspects on a single farm, using a variety of data collection methods both quantitative and qualitative. This allows for observations to be made in context of a specific farm (see Maxwell, 1986; Padel, 2002). In some cases we used comparative case studies, where this approach was extended to several farms and observations could be compared between different farms.

- On-farm trials introduced a specific treatment (e.g. use of new feed resources) which was compared with a control group or with performance before the treatment was introduced.

- Several projects were carried out as group discussion, which are the facilitated exchange of farmer experience and other knowledge sources among participating farmers with the aim to improve practice. This approach is inspired by the Farmer Field Schools (SUSTAINET EA, 2010), the Danish concept of Stable Schools (Vaarst et al., 2007), the approach of field labs developed in the UK (MacMillan \& Benton, 2014) and focus groups.

The choice of method depended on the topic under study and in some cases involved the combination of some of the elements. A common template for reporting outlining also the farmers' background to a specific topic and the experience with the approach was developed.

\section{Experience So Far}

\subsection{Identifying Research and Innovation Needs}

Evaluating the sustainability of selected farms was intended to 'set the scene' and consider sustainability in its broadest sense whilst identifying suitable topics for participatory research. The results illustrate the diversity of low-input and organic dairy farms in the nine countries in terms of size and intensity. Cow farms varied from less than 20 ha (Austria and Italy) to more than 400 ha (Denmark, UK), with herd sizes ranging from nine (Finland) to over 300 cows (Italy, Denmark, UK) and milk yields ranging from less than $2500 \mathrm{~kg} / \mathrm{cow}$ (Austria and Romania) to more than 8000 1/cow (Denmark). There was landless dairy goat farming in Spain and Flanders, but also grazing on more than 300 ha of common land in Spain and Greece with herd sizes between 22 goats (Spain) and 1150 (Belgium) and milk yields between 117 and 900 1/year. After the assessment, twelve workshops were held to identify knowledge and research needs from the farmers' point of view. They were attended by 161 dairy producers (the majority of which kept cows) in nine countries, and by some staff of the SMEs and facilitated by researchers and/or consultants. The farmers welcomed the opportunity to participate, related to their view that research specifically providing knowledge for organic/low input production was lacking. Further details of the outcomes of the sustainability and the workshops are reported by Leach et al. (2013).

Carrying out a structured sustainability assessment stimulated discussion, both during the visit and in the group meetings. Most farmers' own perception of sustainability included economic sustainability. Exposed to changing markets they do not see any future in farming, if they cannot run the businesses profitably, but the farmers were also aware of some other components of sustainability. The use of the tool encouraged them to think about the wider aspects. Some topics initially viewed sceptically, sparked interest and led to further discussion and some topics emerged from the sustainability assessments. For example, biodiversity management was discussed at first very critically among the mountain farmers in Austria but was eventually chosen as the research topic. Farmers in Denmark and in the UK strongly felt that they should improve in relation to greenhouse gas emissions by using more renewable energy and to diversify their farms. 
Topics for which the farmers wanted to see further research effort have been summarized under the broad headings of animal feeding and forage production, natural resource management, animal management, product differentiation and marketing.

\subsection{Feeding Practices and Forage Production}

Topics included forage quality (i.e. protein), forage productivity and reliability, establishment and utilization of forage crop (such as diverse swards) and cultivation and feed value of protein rich crops (such as lupins, beans, and lucerne). Many dairy farmers reported not feeling confident about growing these crops, despite existing information on the subject. There were also a range of very specific suggestions, such as equipment and energy needs for drying forage (Austria), using various plant species (including for browsing) and identifying drought resistant plants and varieties (Italy, Romania, Spain, UK). Interest in diverse pastures was related to several different expected benefits, such as using them as natural sources for the supply of minerals (mainly in Denmark), improvements in forage quality (UK), creating marketing opportunities through improved product qualities (Austria, Italy) and improving soil quality (UK, see 3.2.2). The Greek farmers were interested in the use of irrigation for pastures. The use of novel forage is also investigated in other parts of the SOLID project (e.g. Rinne et al., 2014).

Some unusual feeding practices used on farms could be applied more widely, illustrating the potential value of knowledge sharing. Goat farmers in the Netherlands used by-products from a muesli factory and Austrian cow farmers 'grass cobs' to reduce purchased concentrate. The cultivation of some vetches as feedstuffs for goats was commonly place in some countries, but considered innovative elsewhere. Romanian farmers referred to trying 'forgotten' feeds such as turnips, millet and sorghum. The discussions and suggestions for further research show that good use of forage is of vital importance for low-input and organic dairy farms, but there is a lack of confidence in the reliability of forage production both in terms of quantity and quality.

\subsection{Natural Resource Management}

Farmers in the UK wanted a better understanding of the soil to be able to diagnose potential problems with declining productivity under organic conditions and suggested research into topics of increasing soil organic matter. Austrian farmers discussing manure application were not fully aware of the considerable amount of information that already exists on this subject.

Farmers in Denmark and Finland showed the greatest concern about energy use and climate change, perhaps as a result of national policies and legislation and the demonstration of energy saving practices. The Austrian farmers used biomass from their own forest to fuel a hay drying installation. The assessment of environmental impact of low-input and organic dairy farming is a topic that is also covered elsewhere in the SOLID Project (e.g. Hietala et al., 2014).

\subsection{Animal Management}

Despite some ongoing research on the subject, the choice of cow breeds and animals best suited to low input and/or organic systems was raised as research need in Denmark, Austria, Italy and the UK and by the goat farmers in Greece. The suitability of breeds for organic and low-input systems is also investigated in on-station experiments of the SOLID project (e.g. Horn et al., 2013).

Although animal health and welfare scored well in sustainability assessment, the farmers identified at least one health or welfare related issue in each workshop, including using fewer antibiotics (UK), improving health and longevity (Finland), parasite and disease control in goats (Belgium) and determining risk factors for neonatal losses and sub-clinical mastitis (Greece), even if on many of these subjects, research knowledge is available. Less common practices with innovative potential included seasonal calving and rearing calves on mothers and nurse cows (UK and Denmark), once-a-day milking (UK) and extending goat lactations (Belgium).

\subsection{Product Differentiation and Marketing}

Farmers were interested in product differentiation and in improved communication with consumers about the value of their products. One Italian farm aimed to standardize a high forage diet to market milk with a high nutritional value. This topic has been studied in several research projects (several authors cited by Leach et al., 2013) but so far farmers or SMEs have not developed related differentiation strategies. The topic was not taken up further in this project.

Farmers used specific attribute in selling directly to the public, e.g. in connections with agro-tourism in Austria, by offering a good product range in Greece or by selling raw milk through authorized dispensing machines in Romania. In Spain, one cheese-making farm developed an 'a la carte' strategy, targeting high-end restaurants for 
different types of flavored goat cheeses (matured in olive oil, with herbs).

\subsection{Setting up the Participatory Research Projects}

The next stage involved further discussions to narrow down the topics, because the number of projects in each country was limited. Setting the 'right' research question is important for the successful conduction and the quality of any research and this is equally important for participatory studies. In this case, the experience of the farmers' in what treatments can be implemented and what indicators can be monitored under practical conditions had to be brought together with the researchers' knowledge of experimental design, data analysis and statistics. The process is illustrated with two UK examples.

One UK farmer, with the aim of increasing soil organic matter, established very diverse and herb-rich swards and grazes in an extended rotation, along the lines of "mob grazing". The topic was of interest also to several other UK farmers, so a case study for monitoring the farm was developed (Leach et al., 2014).

The UK SME partner wanted to further explore the link between diet and cow health on a number of farms. However, given the variability on management practices across farms and the difficulty in identifying parameters that could be manipulated under practical conditions of different farms made clear that this question was not suitable for this type of research. As a result we opted for an approach that can account for potential confounding effects due to different farm practices and conditions with the aim to study how different farm management practices can affect the concentration of iodine in milk in view of the iodine supplied by the feed which was also of great interest to the SME partner.

The final choice of topics summarized in Table 1 reflects priority for the farmers and suitability for on- farm research, and a suitable approach was developed using the different methods described in Section 2.2. Although farmers in several countries were also very interested in product differentiation and marketing no on-farm experiments were selected in this area, but the results of Austrian, Italy studies could support this in future.

Table 1. Topics of farmer-led research in the SOLID* project and the adopted study methods

\begin{tabular}{|c|c|c|c|}
\hline Thematic area & Topic & Approach & Country \\
\hline \multirow[t]{3}{*}{ Feeding and forage } & Home grown proteins & On-farm trials & Finland \\
\hline & Use of by-products & On-farm trials & Spain, Romania \\
\hline & Irrigation of pasture & On-farm trial & Greece \\
\hline \multirow[t]{4}{*}{$\begin{array}{l}\text { Natural resources use } \\
\text { and environmental } \\
\text { impact }\end{array}$} & $\begin{array}{l}\text { Soil management, pasture } \\
\text { productivity and grazing }\end{array}$ & $\begin{array}{l}\text { Farm case study with } \\
\text { monitoring of forage } \\
\text { production }\end{array}$ & United Kingdom \\
\hline & Responding to climate change & $\begin{array}{l}\text { Moderated discussion group } \\
\text { and farm case studies }\end{array}$ & Denmark \\
\hline & $\begin{array}{l}\text { Impact of different protein } \\
\text { sources on carbon footprint }\end{array}$ & $\begin{array}{l}\text { Case study using LCA (Life } \\
\text { Cycle Analysis) method }\end{array}$ & Italy \\
\hline & $\begin{array}{l}\text { Impact of intensification on } \\
\text { biodiversity }\end{array}$ & $\begin{array}{l}\text { Comparative farm case } \\
\text { studies with assessments } \\
\text { and modelling }\end{array}$ & Austria \\
\hline \multirow[t]{4}{*}{ Animal management } & Reducing antibiotic use & $\begin{array}{l}\text { Moderated discussion group } \\
\text { followed by on-farm trials }\end{array}$ & $\begin{array}{l}\text { United Kingdom } \\
\text { (jointly with } \\
\text { DFF ) }\end{array}$ \\
\hline & Herbs in pasture & Comparative case studies & Denmark \\
\hline & $\begin{array}{l}\text { Maternal /nurse cow rearing of } \\
\text { calves }\end{array}$ & $\begin{array}{l}\text { Farm case study with } \\
\text { monitoring of calf growth }\end{array}$ & $\begin{array}{l}\text { United Kingdom } \\
\text { and Denmark }\end{array}$ \\
\hline & $\begin{array}{l}\text { Impact of farm practices on } \\
\text { concentration of iodine in milk }\end{array}$ & $\begin{array}{l}\text { Comparative farm case } \\
\text { studies }\end{array}$ & United Kingdom \\
\hline
\end{tabular}

Source: Own data.

* for a description of the protocols and future publication of results please see www.solidairy.eu), SOLID (Sustainable Organic Low-Input Dairying) 
$\sim$ DFF is the Duchy Future Farming program of the Soil Association (http://www.soilassociation.org/fieldlabs).

\section{Discussion}

\subsection{Innovation in Organic Agriculture through Knowledge Exploitation}

The research and innovations topics discuss by the SOLID farmers include many examples of exploitative innovation strategy (see March 1991) where already a considerable amount of research exists. For example, sustainability could be improved by mobilizing knowledge about growing and feeding many different forage crops. Incremental change based on better exploitation of existing knowledge by producers, e.g. through re-combining it in different ways, appears very important for further development of organic and low-input farms, but is not likely to be restricted to these sectors. However, examples of breeding new varieties of forage legumes or other feed crops with high protein content illustrate that there also is a need for explorative innovation.

This importance of both explorative and exploitative strategies is also reflected in responses of low-input and organic dairy farmers to a list of innovation statements that they were shown in another part of the SOLID project. The aim of the survey was to contrast views about acceptability of innovation statements between different actors in the supply chain (farmers, processors/retailers and consumers) in Belgium, Finland, Italy and the UK, using Q sort methodology (Nicholas et al., 2014). The farmers strongly liked statements referring to exploitative innovation, such as developing techniques to improve feed and forage quality, reduce the use of purchased concentrate as well as improving feed quality and efficiency and animal welfare. They disliked some explorative statement that referred to what they saw as 'unnatural' innovation, such originating from GM or semen sexing, but strongly liked statements of 'developing of new forage varieties specific for low input and organic farming' (Nicholas et al., 2014).

\subsection{The Role of Open-Access in Supporting the Innovation Process for Sustainable Development}

In our view, it is also necessary to reflect on who will benefit from future innovation in organic agriculture or related systems. Some innovation will generate specific benefits for farmers, such as increased profitability, but much will generate public benefits, such as reduced natural resource use, improvement of soil fertility, of biodiversity and of animal health. Such innovation is a necessary part of sustainable development. We agree with the conclusion of Buckwell et al. (2014) that as part of sustainable intensification of European agriculture the 'knowledge per hectare' should to be intensified, including knowledge about how to manage the ecosystem services on which agriculture relies. We would like to emphasize again that 'innovation' is not necessarily a product, but a reflected part of continuous process, which involves creative thinking and knowledge sharing through learning in communities. In the United States, the idea of the open-access knowhow to farming is well established but also in Europe there are some good examples of open-access, for example the research archive for organic agriculture (e.g. http://orgprints.org).

\subsection{How Can Locally Generated Knowledge Be Valuable in Other Contexts?}

We believe there are three main reasons that limit the universal nature of locally-generated knowledge: ecology, economic and market context, and social/cultural values. Knowledge about the ecology of the given environment is location-specific and becomes only transferable where workable model of the ecological interactions under various pedo-climatic conditions exists. The interest in increasing home-grown protein crops illustrates that sharing relevant knowledge about specific crops could help the farmers to become more confident in growing them, but uncertainty remains under which conditions which corps are worth trying. And organic sector development will influence access to specific organic inputs, for example for organic feed. Finally, existing knowledge is also specific to personal goals and styles, social norms and cultural contexts. Curry and Kirwan (2014) conclude that the complex set of objectives, values and styles of implementing sustainability agriculture at various locations has an impact on how much knowledge can be seen as universal.

Farmers are aware that research often excludes variables that they know to be important for their decision-making but they may feel unable to express these clearly. This is likely to be a reason why they often have greater trust of farmers than of other experts. The farmer (tacit) knowledge, grounded in the farmers' observations of the various parts of their system and of the local environment, is important for the success or failure of new practices. Therefore farmers need to be recognized as active contributors to generating innovation rather as than passive recipients of knowledge transfer.

However, science derived knowledge cannot be replaced by context or farmer knowledge. Science derived knowledge needs to include basic ecological principles and the state of resources and ecosystem services on which agriculture depends. To foster innovation, this scientific knowledge must be complemented by location 
specific knowledge related to the ecology, economics and culture. And farmers and researchers as the two main actor groups contributing knowledge (as well as advisors, consultants and other intermediaries) need work closely together. The experience in SOLID has shown that farmer-led research is a good way to stimulate this dialogue between the farmers and scientists as equal partners in trying to find solutions to the problems experienced by the farmers and develop sustainability.

\subsection{Supporting Active Farmer Learning for Innovation for Sustainability}

How should such knowledge exchange systems be organized to support innovation for sustainability of agriculture? This shift away from dissemination and 'technology transfer' towards recognizing the role of farmers implies learning as active knowledge construction (Koutsouris, 2012). Farmers need to become confident observers of their own systems, so that they can learn the lessons, draw their own conclusions and recombine elements to develop their own solutions. The discussions among UK farmers identifying soil fertility as a research topic illustrate this point: some organic farmers had observed that productivity of some of their swards had dropped, but did not feel that could identify the causes and implement solutions using standard soil analysis so they wanted to know more about biological soil processes. Ongoing activities in the project are aimed at testing simple diagnostic tools that the farmers can use.

A study of learning and Innovation Networks for Sustainable Agriculture (LINSA) concluded that such groups' need to adopt a strong focus on the process of learning to effectively support innovation in the farming sector. In particular, the dimension of social learning with groups of farmers has received attention, but this is not to say that education in schools and colleges does not deserve to be considered to foster change. In the LINSA groups, social learning emerges from a shared interest in a problem, challenge or activity and all the actors bring all their expertise to the table. Social learning is linked to processes of trust building, trial and error and of mutual support and can provide answers to very complex problems, because mutual reflection on knowledge and consciously hearing different perspectives on one common issue will enhance the portfolio of potential solutions (Moschitz et al., 2014).

\section{Conclusions}

- The conceptual framework of innovation systems uses a broad definition of innovation and describes it as the outcome of a stakeholder interaction process. This framework is more suited to understand and support innovation for sustainability and within organic agriculture than the technology transfer model.

- Farmers are active contributors to agricultural innovation, who contribute context specific knowledge as well as their creativity. The restrictions of certain inputs and the focus and direction of organic standards encourage organic farmers to try a range of alternative solutions.

- Knowledge exploitative and explorative innovation strategies are likely to be equally important to improve sustainability of organic and low-input dairy farming. An example of exploitation is improving forage production and utilization, and examples of explorative innovation are new forage cultivars and species.

- Innovation for sustainability generates private but also much public benefits, such as reduced natural resource use, improvement of soil fertility, of biodiversity and of animal health. The open-access model of knowledge sharing is compatible with supporting this process and should be more widely used.

- Knowledge exchange supporting innovation for sustainability needs to bring science-based and farmer (tacit) knowledge together. Farmer-led research is an effective way for researchers and the farmers together to develop sustainability of agriculture.

\section{Acknowledgments}

Funding from the European Community's Seventh Framework Programme (FP7/ 2007-2013) was received for the research leading to these results, under grant agreement no. FP7-266367 (SOLID-Sustainable Organic and Low Input Dairying). For further details, see www.solidairy.eu. We are also grateful for the active participation and support of all the farmers, researchers and SME partners.

\section{References}

Bokelmann, W., Doernberg, A., Schwerdtner, W., Kuntosch, A., Busse, M., König, B., ... Stahlecker, T. (2012). Sektorstudie zur Untersuchung des Innovationssystems der deutschen Landwirtschaft. Berlin: Humboldt-Universität.

Buckwell, A., Nordang Uhre, A., Williams, A., Polakova, J., Blum, W. E. H., Schiefer, J., ... Haber, W. (2014). The sustainable intensification of European agriculture. Brussels: RISE Foundation. 
Chambers, R., Pacey, A., \& Thrupp, L. A. (Eds.) (1989). Farmer First: Farmer Innovation and Agricultural Research, London: Intermediate Technology Publications. http://dx.doi.org/10.3362/9781780440149

Curry, N., \& Kirwan, J. (2014). The Role of Tacit Knowledge in Developing Networks for Sustainable Agriculture. Sociologia Ruralis, 54(3), 341-361. http://dx.doi.org/10.1111/soru.12048

EC-SCAR. (2011). The 3rd SCAR Foresight Exercise. Standing Committee on Agricultural Research (SCAR). Brussels: European Commissin.

EC-SCAR. (2012). Agricultural Knowledge and Innovation Systems in Transition - A reflection paper. Standing Commitee on Agricultural Research - Collaborative Working Group on Agricultural Knowledge and Innovation System (CWG AKIS). Brussels: European Commisssion.

EIP-AGRI. (2012). European Innovation Partnership Agricultural Productivity and Sustainability (EIP AGRI). (COM(2012) 79). Brussels: European Commisssion.

Garnett, T., \& Godfray, H. C. J. (2012). Sustainable intensification in agriculture. Food Climate Research Network and the Oxfrod Martin Programme on the Future of Food. Oxford: Univeristy of Oxford.

Gerrard, C. L., Smith, L. G., Padel, S., Pearce, B., Hitchings, R., Measures, M., \& Cooper, N. (2011). OCIS public goods tool development. Research report. Newbury: Organic Research Centre.

Hall, A., Mytelka, L., \& Oyeyinka, B. (2005). From Innovation systems: Implications for agricultural policy and practice - CGIAR- ILAC Source-book Chapter 3. Retrieved from http://www.cgiar-ilac.org/content/chapter-3-innovation-systems

Hietala, S., Smith, L., Knudsen, M., Kurppa, S., Padel, S., \& Hermansen, J. (2014). Carbon footprints of organic dairying in six European countries - real farm data analysis. Organic Agriculture, 1-10.

Hoffmann, V., Probst, K., \& Christinck, A. (2007). Farmers and researchers: How can collaborative advantages be created in participatory research and technology development? Agriculture and Human Values, 24, 355-368. http://dx.doi.org/10.1007/s10460-007-9072-2

Horn, M., Steinwidder, A., Gasteiner, J., Podstatzky, L., Haiger, A., \& Zollitsch, W. (2013). Suitability of different dairy cow types for an Alpine organic and low-input milk production system. Livestock Science, 153, 135-146. http://dx.doi.org/10.1016/j.livsci.2013.01.011

Knickel, K., Tisenkopfs, T., \& Peter, S. (Eds.). (2009). Innovation processes in agriculture and rural development: Results of a cross-national analysis of the situation in seven countries, research gaps and recommendations, Frankfurt (Main), Germany: IfLS Frankfurt at Goethe Universit.

Koutsouris, A. (2012). Facilitating Agricultural Innovation Systems: a critical realist approach. Studies in Agricultural Economics, 114, 64-70. http://dx.doi.org/10.7896/j.1210

Leach, K., Gerrard, C. L., \& Padel, S. (Eds.). (2013). Rapid sustainability assessment of organic and low-input farming across Europe and identification of research needs, Hamstead Marshall, Newbury: Organic Research Centre.

Leach, K., Palomo, G., Waterfield, W., Zaralis, K., \& Padel, S. (2014). Diverse swards and mob grazing for dairy farm productivity: A UK case study. In Thünen Report, no. 20. Braunschweig: Thünen-Institut. pp. 1155-1158.

Li, Y., Vanhaverbeke, W., \& Schoenmakers, W. (2008). Exploration and exploitation in innovation: Reframing the interpretation. Creativity and innovation management, 17(2), 107-126. http://dx.doi.org/10.1111/j.1467-8691.2008.00477.x

Lockeretz, W. (1991). Information requirements of reduced chemical production methods. American Journal of Alternative Agriculture, 6(2), 97-103. http://dx.doi.org/10.1017/S0889189300003957

MacMillan, T., \& Benton, T. G. (2014). Agriculture: Engage farmers in research. Nature, 508, 25-27. http://dx.doi.org/10.1038/509025a

March, J. G. (1991). Exploration and exploitation in organizational learning. Organization science, 2(1), 71-87. http://dx.doi.org/10.1287/orsc.2.1.71

Marchand, F., Debruyne, L., Triste, L., Gerrard, C., Padel, S., \& Lauwers, L. (2014). Key characteristics for tool choice in indicator-based sustainability assessment at farm level. Ecology and Society, 19(3). http://dx.doi.org/10.5751/ES-06876-190346

Maxwell, S. (1986). The role of case studies in farm systems research. Agricultural Administration, 21, 147-180. 
http://dx.doi.org/10.1016/0309-586X(86)90083-X

McIntyre, B. D., Herren, H. R., Wakhungu, J., \& Watson, R. T. (Eds.). (2009). Agriculture at a crossroads [Global Report by the International Assessment of Agricultural Knowledge, Science and Technology for Development (IAASTD)]: Synthesis Report, Washington DC: International assessment of agricultural knowledge, science and technology for development (IAASTD).

Morgan, K., \& Murdoch, J. (2000). Organic vs. conventional agriculture: knowledge, power and innovation in the food chain. Geoforum, 31(2), 159-173. http://dx.doi.org/10.1016/S0016-7185(99)00029-9

Moschitz, H., Tisenkopfs, T., Brunori, G., Home, R., Kunda, I., \& Sumane, S. (2014). Final report of the Solinsa project. Frick: FIBL.

Nicholas, P. K., Mandolesi, S., Naspetti, S., \& Zanoli, R. (2014) Innovations in low input and organic dairy supply chains-What is acceptable in Europe? Journal of Dairy Science, 97(2), 1157-1167. http://dx.doi.org/10.3168/jds.2013-7314

OECD/Eurostat. (2005). Oslo Manual. Guidelines for Collecting and Interpreting Innovation Data, (3rd Edition). Paris: OECD Publishing.

Padel, S. (2001). Conversion to organic farming: A typical example of the diffusion of an innovation? Sociologia Ruralis, 41(1), 40-61. http://dx.doi.org/10.1111/1467-9523.00169

Padel, S. (2002). Conversion to organic milk production: the change process and farmers information needs. $\mathrm{PhD}$ Thesis, Aberystwyth: University of Wales.

Padel, S., Niggli, U., Pearce, B., Schlüter, M., Schmid, O., Cuoco, E., ... Micheloni, C. (2010). Implementation Action Plan for organic food and farming research. Brussels: TP Organics. IFOAM- EU Group.

Pretty, J., Toulmin, C., \& Williams, S. (2011). Sustainable intensification in African agriculture. International Journal of Agricultural Sustainability, 9(1), 5-24. http://dx.doi.org/10.3763/ijas.2010.0583

Rinne, M., Dragomir, C., Kuoppala, K., Smith, J., \& Yanez Ruiz, D. (2014). Novel feeds for organic dairy chains. Organic Agriculture, 4, 275-284. http://dx.doi.org/10.1007/s13165-014-0081-3

Rogers, E. M. (1983). Diffusion of Innovation. New York: The Free Press.

Röling, N. (2009). Pathways for impact: scientists' different perspectives on agricultural innovation. International Journal of Agricultural Sustainablity, 7(2), 83-94. http://dx.doi.org/10.3763/ijas.2009.0043

Schumpeter, J., Salin, E., \& Preiswerk, S. (1980). Kapitalismus, Sozialismus und Demokratie. München: Francke.

Smiths, R., Kuhlman, S., \& Shapira, P. (2010). The Theory and Practise of Innovation Policy- an international research handbook (cited after EC-SCAR, 2012).

SUSTAINET EA. (2010). Technical Manual for Farmers and Field Extension Service Providers: Farmer Field School Approach. Nairoby: SUSTAINET East Africa. Retrieved from http://www.sustainetea.org/

Vaarst, M., Nissen, T. B., Østergaard, S., Klaas, I. C., Bennedsgaard, T. W., \& Christensen, J. (2007). Danish Stable Schools for Experiential Common Learning in Groups of Organic Dairy Farmers. Journal Dairy Science, 90, 2543-2554. http://dx.doi.org/10.3168/jds.2006-607

Wezel, A., Bellon, S., Dore, T., Francis, C., Vallod, D., \& David, C. (2009). Agroecology as a science, a movement and a practice: A review. Agronomy for Sustainable Development, 29, 503-515. http://dx.doi.org/10.1051/agro/2009004

\section{Copyrights}

Copyright for this article is retained by the author(s), with first publication rights granted to the journal.

This is an open-access article distributed under the terms and conditions of the Creative Commons Attribution license (http://creativecommons.org/licenses/by/3.0/). 